\title{
Virus-like particles associated with dieback symptoms in the brown alga Ecklonia radiata
}

\author{
L. M. Easton, G. D. Lewis *, M. N. Pearson \\ School of Biological Sciences, University of Auckland, Private Bag 92019, Auckland, New Zealand
}

\begin{abstract}
Since 1991 epidemic dieback of the kelp Ecklonia radiata has been observed at the Leigh Marine Reserve and other sites in northern New Zealand. As the dominant phaeophycean E. radiata is a very important component of the eastern coastal ecosystem, providing both food and refuge for many species. Examination of the E. radiata sap extracts by electron microscopy detected the presence of both straight (ca $280 \mathrm{~nm}$ ) and flexuous (ca 700 to $900 \mathrm{~nm}$ ) virus-like filamentous particles. Extracts from several dieback-affected plants also reacted positively with potyvirus group monoclonal antibody.
\end{abstract}

KEY WORDS: Ecklonia radiata Kelp Virus-like particles Potyvirus

\section{INTRODUCTION}

Virus-like particles have been detected in at least 44 taxa of eukaryotic algae (Van Etten et al. 1991). In most cases reports are of a single observation of particles during microscopic studies and characterisation of these particles has not been pursued. Polyhedral viruslike particles have been detected in the green algae, red algae and filamentous brown algae (Lee 1971, Markey 1974, Dodds 1979, Van Etten et al. 1991، Müller \& Stache 1992), including 2 species of filamentous brown algae from New Zealand (Henry \& Meints 1992, Müller \& Stache 1992). All of these viruses exhibit similar structural characteristics, being polyhedral particles with a double stranded DNA genome (Müller \& Frenzer 1993, Friess-Klebl et al. 1994).

Chara australis virus (Gibbs et al. 1975), a virus infecting the freshwater macrophytic green alga $C$. australis, is the only known algal virus which resembles vascular plant viruses (Van Etten et al. 1991). This virus has been isolated from the sap of $C$. australis and apart from its size (530 $\mathrm{nm}$ long) resembles the particles of tobacco mosaic virus (Gibbs et al. 1975, Skotnicki et al. 1976). Infection of healthy cells by injection with purified particles results in chlorosis and death in 10 to $12 \mathrm{~d}$ (Skotnicki et al. 1976) and replication of

\footnotetext{
- Addressee for correspondence.

E-mail: gd.lewis@auckland.ac.nz
}

virus particles is also seen to occur within infected cells (Gibbs et al. 1975.) The genome of this virus has been characterised and consists of a single-stranded RNA. The nucleotide sequence (Brunt \& Richards 1989) suggests that it may be more closely related to the furoviruses than the tobamoviruses (Van Etten et al. 1991).

Noticeably absent from the types of algae from which viruses have been recovered are the larger fucoid and laminarian algae. This is possibly because most viruses or virus-like particles found in the algae have been discovered by chance during ultrastructure studies related to the life history, rather than during investigation of disease.

Ecklonia radiata (C. Agardh) J. Agardh 1848, is a large perennial kelp (Laminariales, Alariaceae) which is common along the eastern coastline of New Zealand, where it is the dominant phaeophycean (Novaczek 1980) and forms extensive forests. In late 1991 dieback of the kelp was observed at about $15 \mathrm{~m}$ depth in a restricted area of the Cape Rodney to Okakari Point Marine Reserve in Northern New Zealand. Affected plants are characterised in the early stages by lightcoloured patches on the laminae, associated with increased rates of erosion of laminae. The number and size of the laminae are reduced until only the stipe remains, before eventual disintegration, when even the holdfast disappears (Babcock \& Cole 1993, Cole \& Babcock 1996) (Fig. 1). 
A
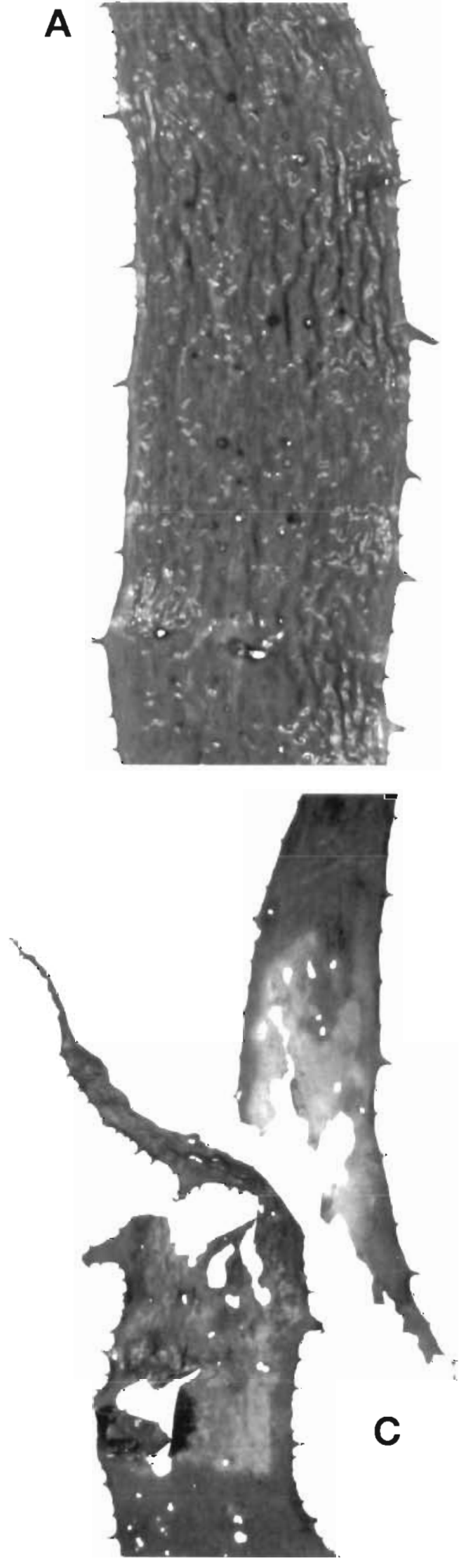

B
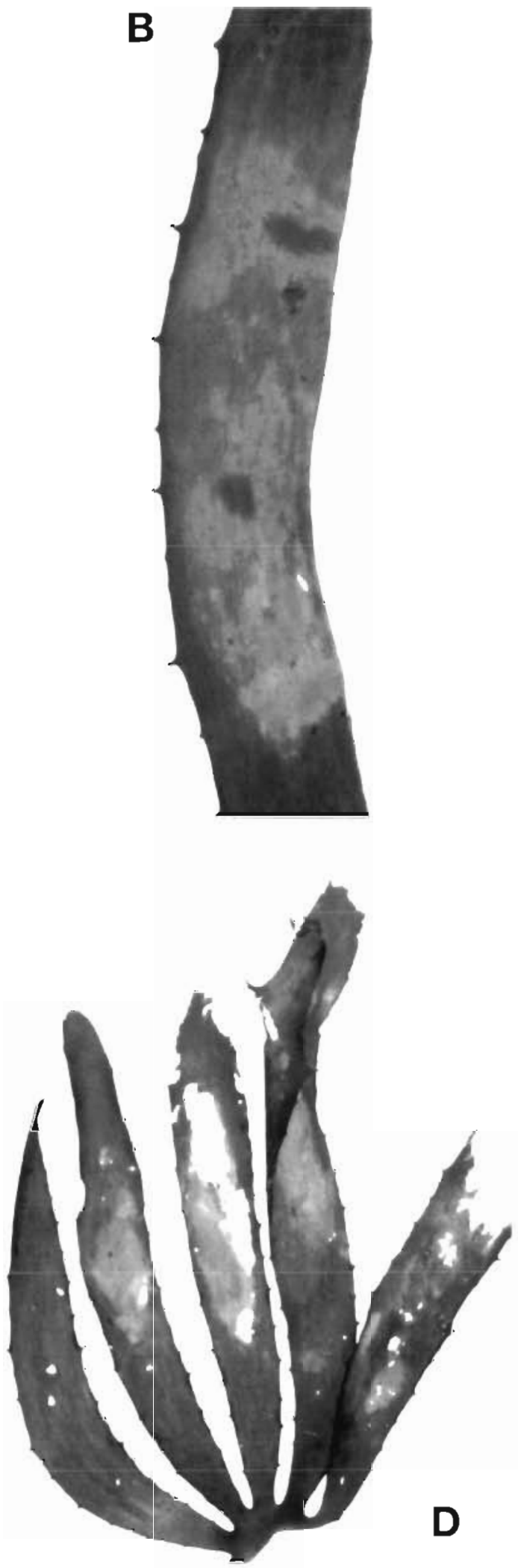

Fig. 1. Ecklonia radiata. Progressive symptoms of dieback. (A) Unaffected, (B) early stage lesion showing reduction in pigmentation. (C) advanced degradation, (D) frond showing various stages of dieback symptoms 
Extensive dieback in other parts of the reserve was noticed in November 1992, with large numbers of plants at 15 to $20 \mathrm{~m}$ depths being affected. Between January and May 1993 plants in mid-depths (9 to $12 \mathrm{~m}$ ) became increasingly affected, while deeper plants (15 to $18 \mathrm{~m}$ ) in some areas suffered 90 to $100 \%$ mortality. Throughout 1993 the dieback continued spreading to shallow depths which were initially unaffected (Babcock \& Cole 1993). Similar dieback has also been reported at a number of other sites in northern New Zealand, but none so extensive, or as well documented as that observed in the Cape Rodney to Okakari Point Marine Reserve (Babcock \& Cole 1993, Cole \& Babcock 1996).

\section{MATERIALS AND METHODS}

Electron microscopy. Small pieces ( 3 to $4 \mathrm{~mm}$ ) of dieback-affected kelp tissue were crushed in $1 \%$ aqueous phosphotungstic acid, pH 7.0 and a drop of the stain/sap mixture placed onto a parlodion-coated, carbon-stabilised copper grid. Excess liquid was removed and the negatively stained samples viewed under a Philips 310 S transmission electron microscope. Sap extracts from healthy kelp were used as negative controls.

Plant inoculations. Extracts of kelp laminar tissue from plants at 5 different stages in symptom development were mechanically inoculated to Chenopodium quinoa, Petunia hybrida, Nicotiana benthamiana, $N$. glutinosa, $N$ tabaccum. The kelp laminar tissue was triturated in $0.01 \mathrm{M}$ Sorensens phosphate buffer, pH 7.2 $(1: 10, \mathrm{w} / \mathrm{v})$ using a pestle and mortar and rubbed gently on expanded leaves of the test plants which had been dusted lightly with 500 mesh carborundum.

Serology. Plant samples were tested for the presence of potyvirus using a potyvirus virus group monoclonal antibody (Agdia Corp., Elkhart, USA) in an antigen coated plate (indirect) ELISA, according to the suppliers protocol. Tissue samples from kelp and herbaceous species were homogenised $1: 10 \mathrm{w} / \mathrm{v}$ and $1: 100 \mathrm{w} / \mathrm{v}$, respectively, in the extraction buffer (sodium carbonate/bicarbonate, $\mathrm{pH}$ 9.6). These ratios were chosen following optimisation experiments (data not shown). Following the addition of the enzyme substrate, the $\mathrm{Abs}_{405}$ (absorbance at $405 \mathrm{~nm}$ ) was measured after $30 \mathrm{~min}$ incubation in the dark using a Bio-Tek EL307B EIA reader. Healthy Ecklonia radiata plants from a site where dieback is absent were used as controls. Samples were tested in triplicate and were regarded as positive when $\mathrm{Abs}_{405}$ readings were greater than the mean of the control plus 3 standard deviations. Sap from dasheen mosaic potyvirus (DMV)-infected taro was used as a positive control.

\section{RESULTS}

\section{Electron microscopy}

Two types of virus-like particles (VLPs) were observed in lamina samples of diseased Ecklonia radiata, rod-shaped (tobamovirus-like) particles $280 \mathrm{~nm}$ long (Fig. 2a) and flexuous filamentous (potyvirus-like) particles 700 to $900 \mathrm{~nm}$ long (Fig. 2b). Results are summarised in Table 1. VLPs were observed in 7 of the 15 diseased plants examined, although they were not observed in all of the samples taken from each plant. Tobamovirus-like particles were observed in 4 of the plants, while potyvirus-like particles were observed in 5 . On 2 occasions both types of particles were observed in samples from the same plant. The numbers of particles observed on each grid was very low, with only 9 or 10 particles seen on the best grids. No VLPs were observed in extracts of healthy kelp, or in stained phosphate-buffered saline (PBS) controls.

\section{Plant inoculations}

No local lesions or systemic virus-like symptoms developed on any of the herbaceous plants inoculated with sap extracts from dieback-affected Ecklonia radiata. Enzyme-linked immunosorbent assay (ELISA) tests on the inoculated plants $4 \mathrm{wk}$ after inoculation using the potyvirus group antibody were all negative.

\section{Serology}

Five out of 15 dieback-affected Ecklonia radiata plants gave clear positive reactions to the potyvirus group test when mature laminar was tested (Table 2). In addition, 2 apparently healthy plants collected from a dieback site gave a positive potyvirus test. These

Table 1. Ecklonia radiata. Presence of virus-like particles in negatively stained sap samples from dieback-affected and healthy plants

\begin{tabular}{|c|c|c|c|c|}
\hline \multirow[t]{2}{*}{ Sample type } & \multirow{2}{*}{$\begin{array}{l}\text { Number } \\
\text { examined }\end{array}$} & \multicolumn{3}{|c|}{ Number of samples containing virus } \\
\hline & & $\begin{array}{l}\text { Flexuous and } \\
\text { straight rods }\end{array}$ & $\begin{array}{l}\text { Flexuous } \\
\text { rods only }\end{array}$ & $\begin{array}{l}\text { Straight } \\
\text { rods only }\end{array}$ \\
\hline Dieback-affected & 15 & 2 & 4 & 3 \\
\hline Healthy & 6 & 0 & 0 & 0 \\
\hline Buffer control & 5 & 0 & 0 & 0 \\
\hline
\end{tabular}



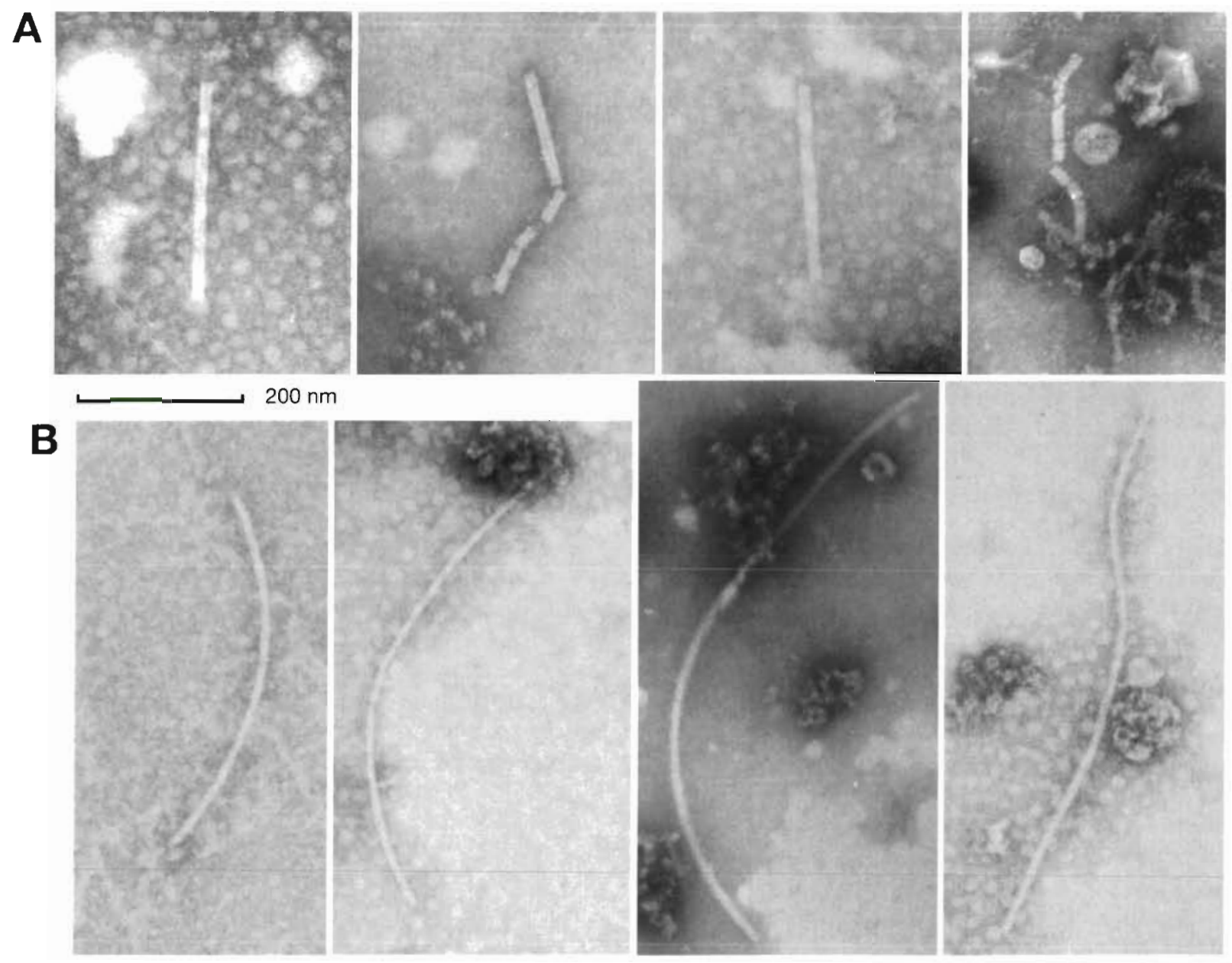

Fig. 2. Ecklonia radiata. Electron micrograph of virus-like particles observed in the alga. (A) Tobamovirus-like particle(s), (B) potyvirus-like particles

plants subsequently developed progressive dieback symptoms with the associated increase in ELISA Abs Abo $_{45}$ readings (Fig. 3). A subsequent comparison of potyvirus detection in different tissues of dieback-affected plants indicated that virus was most likely to be detected in mature laminar and sorus (Table 2).

\section{DISCUSSION}

Two types of virus-like particles were observed only in diseased Ecklonia radiata. The smaller rigid straight rods were similar in size and appearance to tobamoviruses ( $300 \mathrm{~nm}$ long) and furoviruses (250 to $300 \mathrm{~nm}$ ) (Francki et al. 1991). The flexuous filamentous particles were similar in appearance to members of the potyvirus group, which range in length from 680 to $900 \mathrm{~nm}$ (Francki et al. 1991). The potyviruslike particles were more frequently associated with dieback symptoms than were the tobamovirus-like particles.

Although VLPs were observed in only 7 of 15 diseased samples examined by electron microscopy, they

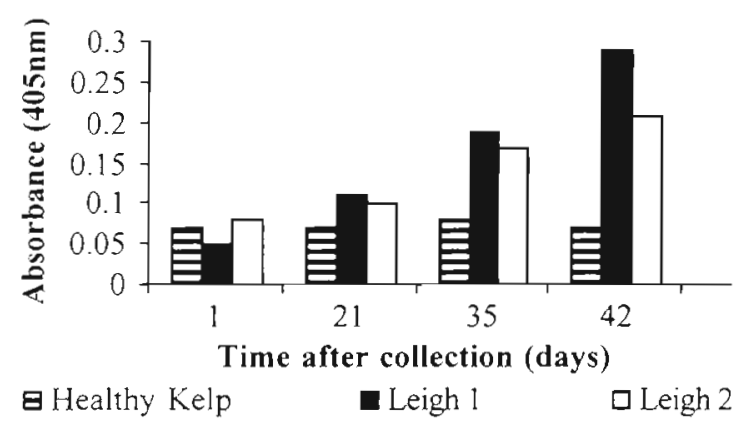

Fig. 3. Ecklonia radiata. Change in potyvirus detection by ELISA in 2 plants developing dieback symptoms in laboratory culture as compared to healthy controls 
Table 2. Ecklonia radiata. Presence of potyvirus in plants as determined by ELISA using the Agdia ${ }^{\text {TM }}$ potyvirus group test

\begin{tabular}{|c|c|c|c|c|}
\hline $\begin{array}{l}\text { Kelp } \\
\text { sample type }\end{array}$ & $\begin{array}{l}\text { ts tested } \\
\text { (no.) }\end{array}$ & $\begin{array}{l}\text { Clear } \\
\text { positive }\end{array}$ & $\begin{array}{l}\text { Marginal } \\
\text { positive }^{c}\end{array}$ & Negative \\
\hline Healthy (mixed tissue types) & 14 & 0 & 0 & 14 \\
\hline \multicolumn{5}{|l|}{ Dieback-affected } \\
\hline \multicolumn{5}{|l|}{ Batch 1} \\
\hline \multicolumn{5}{|l|}{ Batch 2} \\
\hline Sorus & 15 & 5 & 1 & 9 \\
\hline Young secondary laminar & 2 & 0 & 0 & 2 \\
\hline Mature secondary laminar & 9 & 5 & 1 & 3 \\
\hline Primary laminar & 3 & 0 & 0 & 3 \\
\hline Meristem & 3 & 0 & 0 & 3 \\
\hline Stipe & 3 & 0 & 0 & 3 \\
\hline \multicolumn{5}{|c|}{$\begin{array}{l}\text { "Results are based on the mean of } 3 \text { replicate samples from each plant } \\
\text { tested } \\
\text { "A plant was considered a clear positive when the mean absorbance at } \\
405 \mathrm{~nm}\left(\mathrm{Abs}_{405} \text { ) for the } 3 \text { replicate samples was greater than the mean }\right. \\
\text { Abs }{ }_{405} \text { plus } 3 \text { standard deviations of the controls } \\
\text { "A plant was considered a marginal positive when the mean Abs }{ }_{405} \text { for } \\
\text { the } 3 \text { replicate samples was greater than the mean Abs } \text { A }_{405} \text { plus } 2 \text { stan- } \\
\text { dard deviations of the controls (but less than the mean plus } 3 \text { standard } \\
\text { deviations) }\end{array}$} \\
\hline
\end{tabular}

and plant part chosen for study (Hill 1984), and consistent virus recovery generally requires some knowledge of the host/virus relationship. Preliminary results for different tissues indicate that there are tissue differences which should be further studied. As this knowledge of kelp-associated viruses is not available, it is not unexpected that viruses were not detected in all samples.

The serological tests indicated the presence of a potyvirus (or serologically related virus) in some diseased Ecklonia radiata, although a consistent association with dieback symptoms was not observed. Typically the $\mathrm{Abs}_{405}$ for a positive sample was only 3 times greater than that for healthy samples. This may be due in part to low virus titre but it was also observed that the addition of $10 \%$ healthy kelp extracts to DMV-infected taro extracts depressed the $\mathrm{Abs}_{405}$ readings by $60 \%$. Since taro sap itself depresses the $\mathrm{Abs}_{405}$ of purified DMV solutions (Saelea 1996), this suggested that kelp extract inter-

may also have been present in some of the other samples. It is not unusual to obtain negative results by electron microscopy, especially when as in this case, particles are in very low concentration. Nicolaieff \& van Regenmortel (1980) showed that the adsorption of virions to grids is a highly selective process and that the particles which remain on the grid are not a random sample of those present in the suspension. Different particles possess variable specific affinities for the film surface, and, in addition, a 'wash-off' phenomenon often occurs when particles are stained (Milne 1984). Crude sap constituents have also been found to affect the adsorption of virus particles to grids (Nicolaieff \& van Regenmortel 1980, Milne \& Lesemann 1984), and the viscous nature of kelp extracts could have an inhibitory effect. All samples were highly viscous, and large amounts of cellular debris were observed on grids. Microfuged samples had lesser quantities of cellular debris present; however viscosity of the extracts was still considerable. It is possible that treatment of extracts prior to adsorption onto electron microscope grids could result in observation of greater numbers of virus particles. However, some viruses occur in such low concentration that detecting them by simple electron microscope techniques is unreliable (Hill 1984). It is possible that the VLPs present in Ecklonia radiata dieback affected plants may fall into this category. In addition, for many host/virus combinations the likelihood of finding particles in an electron microscope preparation varies with the age of the plant feres with the potyvirus group tests to a sustantial degree.

The ELISA data (Table 2) also indicate that the results are influenced by the type of tissue tested with mature laminar giving the greatest number of positive results. The stage in disease development may also be a factor.

This is the first reported case of VLPs found in a laminarian kelp. The absence of other reports of viruses in kelps is, most likely, due to lack of research in this field, rather than reports that the virus is absent (Dodds 1979, Van Etten et al. 1991). Previous virus and VLP discoveries in algae have occurred during microscopic investigations of the ultrastructural aspects of algae life history, rather than an investigation of a disease (Van Etten et al. 1991). The observed presence of 2 different types of VLPs indicates that VLPs may in fact be relatively common in kelps. This has been found to be the case for filamentous brown algae (Müller \& Stache 1992). It is possible, and relatively common in nature, for an individual plant to be simultaneously infected with 2 or more distinct viruses, which may interact imperceptibly, antagonistically, or synergistically (Cooper \& MacCallum 1984). While the majority of diebackaffected plants $(68 \%)$ tested positive to the Potyvirus Group antiserum, this does not rule out the observed tobamovirus-like particle as a cause of the dieback. It is possible, based on morphology, that this particle may in fact be related to the furovirus group, as is the only other rod-like algal virus, Chara australis virus (CAV) (Van Etten et al. 1991) 
Acknowledgements. This work was supported by a grant from the New Zealand Lotteries Commission-Lotteries Scientific Fund and Robert C. Bruce Trust.

\section{LITERATURE CITED}

Babcock RC, Cole RG (1993) The extent of die-back of the kelp Ecklonia radiata in the Cape Rodney to Okakari Pt. Marine Reserve. Conservation Advisory Science Notes no. 44. Department of Conservation, Wellington

Brunt AA, Richards KE (1989) Biology and the molecular biology of furoviruses. Adv Vir Res 36:1-32

Cole RG, Babcock RC (1996) Mass mortality of a dominant kelp (Laminariales) at Goat Island, North-eastern New Zealand. Mar Freshwater Res 47:907-911

Cooper JI, MacCallum FO (1984) Viruses and the environment. Chapman and Hall, London

Dodds JA (1979) Viruses of marine algae. Experientia 35(4): $440-442$

Francki RIB, Fauquet CM, Knudson DC, Brown F (eds) (1991) Classification and nomenclature of viruses. 5th Report of the International Committee on Taxonomy of Viruses. Arch Virol (Suppl 2). Springer-Verlag, Wien

Friess-Klebl A, Knippers R, Müller DG (1994) Isolation and characterisation of a DNA virus infecting Feldmannia simplex (Phaeophyceae). J Phycol 30:653-658

Gibbs A, Skotnicki AH, Gardiner JE, Walker ES (1975) A tobomovirus of a green alga. Virology 64:571-574

Henry EC, Meints RH (1992) A persistant virus infection in Feldmannia (Phaeophyceae). J Phycol 28:517-526

Editorial responsibility: Silvano Bonotto, Torino, Italy
Hill SA (1984) Methods in plant virology. Blackwell Scientific Publications, Oxford

Lee RE (197.1) Systemic viral material in the cells of the freshwater red alga Sirodotia tenuissima (Holden) Skuja. J Cell Sci 8:623-631

Markey DR (1974) A possible virus infection the brown alga Pylaiella littoralis. Protoplasma 80:223-232

Milne RG (1984) Electron microscopy and plant viruses. Methods Virol 7:87-120

Milne RG, Lesemann DE (1984) Immunosorbent electron microscopy in plant virus studies. Methods Virol 8:85-101

Müller DG, Frenzer K (1993) Virus infections in three marine brown algae: Feldmannia irregularis, F. simplex and Ectocarpus siliculosus. Hyrobiologia 260/261:37-44

Müller DG, Stache B (1992) Worldwide occurrence of virusinfections in filamentous marine brown algae. Helgol Meeresunters 46:1-8

Nicolaieff A, van Regenmortel MHV (1980) Specificity of trapping of plant viruses on antibody-coated electron microscope grids. Ann Virol (Paris) 131E:95-110

Novaczek I (1980) The development and phenology of Ecklonia radiata. Unpublished PhD thesis, University of Auckland

Saelea J (1996) Taro virus detection and characterisation using symptamology, electron microscopy, serology and molecular techniques. Unpublished Msc thesis, University of Auckland

Skotnicki A, Gibbs A, Wrigley NG (1976) Further studies on Chara corallina virus. Virology 75:457-468

Van Etten JL, Lane LC, Meints RH (1991) Viruses and viruslike particles of eukaryotic algae. Biol Rev 55(4):586-620

Manuscript received: April 18, 1997

Revised version accepted: May 25, 1997 